\title{
PRAWA POLITYCZNE CUDZOZIEMCÓW W POLSCE
}

\section{Ivanna Kyliushyk*}

\section{Abstrakt}

Artykuł przedstawia problem stosowania różnych regulacji prawnych dotyczących uprawnień politycznych w stosunku do cudzoziemców z państw Unii Europejskiej i cudzoziemców z państw trzecich w Polsce. Prawa polityczne, które są jednym z mechanizmów inkluzji politycznej, przysługują cudzoziemcom z UE stale zamieszkującym w Polsce, podczas gdy innym cudzoziemcom wraz z nabyciem obywatelstwa. Takie regulacje pozostawiają najliczniejszą grupę cudzoziemców wykluczonymi z lokalnego życia politycznego wspólnoty przyjmującej.

Słowa kluczowe: Prawa polityczne, cudzoziemcy, polityka integracyjna, partycypacja polityczna, inkluzja

\section{Political Rights of Foreigners in POLAND}

\section{Abstract}

The article presents the problem of applying various legal regulations regarding political rights in relation to foreigners from EU countries and foreigners from third countries in Poland. Political rights, which are one of the mechanism of political inclusion, are granted to foreigners from the EU who have permanent residence permit in Poland, then as other foreigners with the acquisition of citizenship. Such regulation leaves the largest group of foreigners excluded from local political life of the host community.

Keywords: Political rights, immigrants, integration policy, political participation, inclusion

\footnotetext{
*Mgr Ivanna Kyliushyk, Uniwersytet Warszawski, e-mail: ivannakyl@gmail.com | ORCID: https://orcid.org/0000-0001-5347-649X
} 
Wprowadzenie

W ciągu ostatnich kilku lat Polska przekształciła się z państwa emigracyjnego w państwo imigracyjne, to znaczy z państwa głównie wysyłającego w państwo głównie przyjmujące imigrantów. Transformacja nastąpiła w konsekwencji wzrostu liczby cudzoziemców ubiegających się o zezwolenia na pobyt na terenie Polski (szczególnie od 2014 roku).

Według danych Urzędu do Spraw Cudzoziemców, w roku 2017 o zezwolenia na pobyt w Polsce ubiegało się 202000 cudzoziemców, co odpowiednio o 33\% i 71\% osób więcej niż w 2016 oraz 2015 roku (Urząd do Spraw Cudzoziemców 2017) ${ }^{1}$.

W następstwie czego, w ciągu ostatnich trzech lat Polska znajduje się na drugim miejscu w Europie po Wielkiej Brytanii pod względem liczby wydanych po raz pierwszy zezwoleń pobytowych dla cudzoziemców, uwzględniając również wizy długoterminowe wydane przez polskie placówki dyplomatyczne (Urząd do Spraw Cudzoziemców b.r.-a).

Zgodnie z najnowszymi danymi, ważne zezwolenie na pobyt na terenie Polski łącznie posiada 366169 cudzoziemców (Urząd do Spraw Cudzoziemców b.r.- b). Te dane jednak nie uwzględniają liczby cudzoziemców przebywających w Polsce na podstawie wiz długoterminowych i krótkoterminowych oraz liczby cudzoziemców przebywających w ramach ruchu bezwizowego.

Mimo stale rosnącej liczby cudzoziemców z państw trzecich osiedlających się w Polsce na podstawie tego czy innego tytułu pobytowego oraz transformacji Polski z państwa wysyłającego w państwo przyjmu-

\footnotetext{
' O zezwolenia na pobyt ubiegało się 192000 obcokrajowców z państw trzecich (spoza Unii Europejskiej). Pobyt zarejestrowało także około 10000 osób pochodzących z państw Unii Europejskiej. Najwięcej wniosków złożyli obywatele Ukrainy (125000 wniosków - 0 30\% więcej niż w 2016 roku). Najczęściej o zezwolenia na pobyt ubiegali się także: Białorusini (9 500), Hindusi (8 000), Wietnamczycy (6 400) oraz Chińczycy (6 000). Odnotowano wzrost ubiegania się o legalizację pobytu wśród obywateli Białorusi oraz Indii, którzy złożyli odpowiednio o 98\% i 95\% więcej wniosków niż w 2016 roku (Urząd do Spraw Cudzoziemców 2017).
} 
jące, cudzoziemcy w Polsce nadal są pozbawieni różnych uprawnień politycznych, które przysługują cudzoziemcom w innych państwach Unii Europejskiej a polski rząd wciąż nie wypracował kompleksowej polityki integracyjnej, która miałaby sprzyjać inkluzji (włączeniu) imigrantów do polskiej wspólnoty.

W październiku 2016 roku rząd Polski uchylił dokument Polityka migracyjna Polski - stan obecny i postulowane działania, przyjęty w 2012 roku. W tym samym czasie ogłoszono o rozpoczęciu prac nad kolejnym nowym dokumentem. Od tego czasu minęły trochę więcej niż dwa lata, a nowy dokument nadal nie został przyjęty i nie wiadomo jaki kształt on będzie mieć i jakie aspekty zawierać.

Celem niniejszego artykułu jest przeanalizowanie politycznych praw imigrantów, cudzoziemców- obywateli państw trzecich oraz cudzoziemców- obywateli państw członkowskich Unii Europejskiej. Takie rozróżnienie nie jest przypadkowe, ponieważ obie grupy różnią się pod względem posiadanych praw politycznych, co wskazuje na asymetrię w polskich regulacjach prawnych dotyczących uprawnień politycznych cudzoziemców pochodzących z Unii Europejskiej (UE) i innych.

Przedmiotem artykułu jest zagadnienie praw politycznych cudzoziemców na szczeblu lokalnym w Polsce z akcentem położonym na prawach wyborczych.

Za prawa polityczne uważam uprawnienia jednostki do udziału w życiu publicznym oraz w sprawdzaniu i kontrolowaniu władzy. Do tych praw zaliczają się: czynne i bierne prawo wyborcze, prawo do udziału w referendum, prawo do zrzeszania się, prawo do rzetelnej informacji i wolności słowa oraz inne.

Prawa wyborcze rozumiem jako uprawnienia do głosowania bądź do kandydowania w wyborach. Czynne prawo wyborcze oznacza uprawnienie do głosowania, bierne prawo wyborcze oznacza uprawnienia do kandydowania. 
Oprócz tego należy wyjaśnić, co autorka rozumie pod niektórymi pojęciami używanymi w artykule. Za cudzoziemca (imigranta) uznaje każdą osobę nieposiadającą obywatelstwa państwa, w którym przebywa. Za cudzoziemca-obywatela państwa trzeciego uważa każdą osobę mającą obywatelstwo państwa niebędącego członkiem Unii Europejskiej czy Europejskiego Obszaru Gospodarczego czy Szwajcarii. Przez inkluzję rozumie proces włączania jednostek, grup czy kategorii społecznych w funkcjonowanie szerszego społeczeństwa. Inkluzja jest zjawiskiem odwrotnym do ekskluzji - wykluczenia społecznego, marginalizacji.

Inkluzja polityczna imigrantów powinna być „[...] wieloetapowym oraz dynamicznym procesem łączącym w sobie trzy wymiary: formalny (status prawny), tożsamościowy (świadomość bycia członkiem wspólnoty) oraz partycypacyjny (aktywne uczestnictwo)" (Lesińska 2013, s. 7).

Wynikiem inkluzji według Magdaleny Lesińskiej ma być „autentyczna możliwość uczestnictwa we spólnocie, w znaczeniu bycia jej aktywnym członkiem, współdecydującym, współodpowiedzialnym, współprzynależnym. Członkostwo we wspólnocie politycznej wyraża pewną trwałą kwalifikację życia społecznego, potwierdza stan przynależności i podmiotowej orientacji, oznacza przyporządkowanie osoby do określonej struktury prawno-politycznej oraz buduje związek między jednostkami pozostającymi w podobnych relacjach. Inkluzja oznacza w końcu upodmiotowienie jednostek z rządzonych na współrządzących, czyli uzyskanie realnych możliwości wpływu na procesy decyzyjne w obrębie danej wspólnoty politycznej poprzez bezpośrednią lub pośrednią partycypację w sferze politycznej i publicznej” (Lesińska 2008, s. 158).

Pod partycypacją polityczną rozumiem wszelką nieobowiązkową aktywność, poprzez którą jednostki bądź grupy społeczne chcą wpływać na wybór rządzących i swoich przedstawicieli i/lub na kształtowanie decyzji politycznych oraz ich rezultaty (definicja wprowadzona przez amerykańskiego politologa Sidneya Verba). 
Prawo głosu w wyborach samorządowych

Najważniejszymi wśród praw politycznych są prawa wyborcze, które są najefektywniejszym mechanizmem inkluzji politycznej cudzoziemców do szeroko rozumianej wspólnoty politycznej, ponieważ dają możliwość wpływać na proces decyzyjny, to znaczy pozwalają na bycie pelnoprawnym członkiem wspólnoty lokalnej.

W 16 państwach spośród 28 krajów Unii Europejskiej prawa wyborcze na szczeblu lokalnym przysługują cudzoziemcom po spelnieniu określonych warunków. Lokalne prawa wyborcze przysługują zarówno cudzoziemcom pochodzącym z państw Unii Europejskiej jak i cudzoziemcom pochodzącym z państw trzecich w Belgii, Danii, Estonii, Finlandii, Hiszpanii, Holandii, Irlandii, Litwie, Luksemburgu, Norwegii, Portugalii, Słowacji, Słowenii, Szwecji, Szwajcarii, na Węgrzech.

Lokalne prawa wyborcze przysługują również cudzoziemcom mieszkającym w Wielkiej Brytanii, jednak Wielka Brytania wyszła ze składu Unii Europejskiej.

W pięciu krajach (Belgii, Estonii, Luksemburgu, Słowenii i na Węgrzech) cudzoziemcom pochodzącym z państw trzecich przysługują jedynie czynne prawa wyborcze, to znaczy bez możliwości kandydowania do organów samorządowych. W pozostałych dwunastu państwach (Austrii, Bułgarii, Cyprze, Czechach, Francji, Grecji, Łotwie, Malcie, Niemczach, Rumunii, Włochach oraz Polsce) nie przewiduje się takich uprawnień dla cudzoziemców pochodzących z państw trzecich.

Poza obywatelami prawa wyborcze w wyborach samorządowych w Polsce przysługują jedynie cudzoziemcom-obywatelom państw Unii Europejskiej zamieszkającym najej terenie. Cudzoziemcy pochodzący z państw trzecich, zamieszkujący na podstawie zezwolenia na pobyt stały czy na podstawie zezwolenia na pobyt rezydenta długoterminowego Unii Europejskiej na czas nieokreślony, takich praw nie mają. 
Parlament Europejski działa na rzecz przyznania cudzoziemcom z państw trzecich praw wyborczych na poziomie lokalnym i w wyborach do Parlamentu Europejskiego. „Stoi bowiem na stanowisku, że »z perspektywy integracji jest oczywiste, że przyznanie praw wyborczych na poziomie lokalnym powinno mieć swoje źródło w pobycie, a nie w obywatelstwie«" (Pudzianowska 2014, s.100).

Kwestie dotyczące lokalnych praw wyborczych określa Konwencja Rady Europy o uczestnictwie cudzoziemców w życiu publicznym na szczeblu lokalnym z 1992 roku, którą do tej pory podpisało trzynaście państw, a ratyfikowało tylko osiem. W Preambule Konwencji wskazuje się na to, iż „stałe zamieszkiwanie cudzoziemców jest obecnie trwałą cechą społeczeństw europejskich w związku z czym istnieje potrzeba wzmocnienia ich integracji ze społecznością lokalną, zwłaszcza poprzez poszerzenie możliwości ich udziału w lokalnych sprawach publicznych. Tym bardziej, że cudzoziemcy zamieszkujący na danym terytorium mają, generalnie, na poziomie lokalnym, takie same obowiązki jak obywatele danego kraju" (Konwencja o uczestnictwie cudzoziemców w życiu publicznym na szczeblu lokalnym 1992, preambuła).

Rozdział A Konwencji poświęcony jest prawu wolności wyrażania opinii, zgromadzania się i stowarzyszania się. W artykule trzecim podkreśla się, że każde państwo ma obowiązek zagwarantować cudzoziemcom zamieszkałym na jej terytorium te prawa na tych samych warunkach, co jej własnym obywatelom: „prawo do swobodnego, pokojowego zgromadzania się oraz do swobodnego stowarzyszania się, włącznie z prawem do tworzenia związków zawodowych i przystępowania do nich dla ochrony swoich interesów. Prawo do swobodnego stowarzyszania się zakłada w szczególności, prawo cudzoziemców zamieszkałych na terytorium Strony do tworzenia ich własnych lokalnych stowarzyszeń w celu wzajemnej pomocy, podtrzymywania i wyrażania swojej tożsamości kulturowej lub obrony ich interesów w sprawach wchodzących w zakres kompetencji władzy lokalnej, jak również prawo do przyłączania 
się do każdego stowarzyszenia" (Konwencja o uczestnictwie cudzoziemców w życiu publicznym na szczeblu lokalnym 1992, art. 3).

W rozdziale B, artykule piątym, podkreśla się konieczność zakładania ciał doradczych stale mieszkających cudzoziemców na szczeblu lokalnym, szczególnie w regionie, gdzie zamieszkuje znaczna liczba cudzoziemców, aby dać im prawo do dyskusji i formułowania opinii, życzeń i trosk w sprawach, które szczególnie ich dotyczą, w odniesieniu do lokalnego życia publicznego.

Rozdział C, artykuł szósty, zawiera prawo udziału w wyborach do władz lokalnych. „Państwa-strony zobowiązują się do przyznania każdemu cudzoziemcowi zamieszkałemu na jego terytorium prawo do udziału w głosowaniu oraz prawo do kandydowania w wyborach do władz lokalnych, jeśli spełnia on te same prawne wymagania, które dotyczą obywateli tego państwa" (Konwencja o uczestnictwie cudzoziemców w życiu publicznym na szczeblu lokalnym 1992, art. 6).

J ednak artykuł nie wyłącza możliwości wprowadzenia przez państwo-stronę pewnych kryteriów, które muszą być spełnione przez cudzoziemca, aby mógł korzystać z prawa głosu, chociaż wymogi te mogą nie mieć zastosowania do obywateli danego państwa. Głównym wymogiem jest stałe i legalne zamieszkanie na terytorium państwa przez 5 lat poprzedzających wybory. Również państwo może ograniczyć lokalne prawa wyborcze jedynie do prawa udziału w głosowaniu bez możliwości kandydowania.

Polska nie ratyfikowała Konwencji o uczestnictwie cudzoziemców w życiu publicznym na szczeblu lokalnym, ani nie wprowadziła innych norm prawnych regulujących kwestie polityczne praw cudzoziemców. Chociaż Konstytucja Rzeczypospolitej Polskiej nie stwarza przeszkód do przyjęcia takiego prawa, bowiem artykuł 16 ustęp 1 określa, iż to „ogół mieszkańców jednostek zasadniczego podziału terytorialnego stanowi z mocy prawa wspólnotę samorządową" (Konstytucja... 1997, art. 16). Oznacza to, że Konstytucja RP nie uzależnia przynależności do 
wspólnoty samorządowej od posiadania obywatelstwa polskiego, a tylko od stałego miejsca zamieszkania.

J ak zaznacza Adam Krzywoń, „należy zgodzić się z tezą, że to właśnie fakt zamieszkiwania, a nie obywatelstwa, odgrywa podstawową rolę we wspólnocie samorządowej. Przy wyborze organów jednostek samorządu terytorialnego wchodzi bowiem w grę nie tyle realizacja suwerennych praw narodu, ile praw wspólnoty samorządowej, której członkami pozostają wszyscy mieszkańcy. Organy jednostek samorządu terytorialnego nie mogą być zatem traktowane jako organy reprezentacji narodowej, leczjako podmioty reprezentujące wszystkie osoby zamieszkujące na danym terytorium, niezależnie od obywatelstwa (Krzywoń 2014, s. 172).

Co oznacza, że nadanie prawa głosu cudzoziemcom nie potrzebuje zmiany Konstytucji RP a tylko nowelizacji Ustawy - Kodeks Wyborczy z 5 stycznia 2011 roku. Cojuż miało miejsce wnajnowszej historii Polski, a mianowicie w 2004 roku, kiedy została przyjęta Ustawa o zmianie ustawy - Ordynacja wyborcza do rad gmin, rad powiatów i sejmików województw. Ustawa nadała czynne i bierne prawa wyborcze cudzoziemcom-obywatelom krajów UE w wyborach na szczeblu lokalnym oraz w wyborach do Parlamentu Europejskiego. Zmiany ordynacji w wyborach na poziomielokalnym zostały wprowadzone wrazz wejściem Polski do Unii Europejskiej. Było to wymaganą koniecznością dostosowania przez Polskę prawa krajowego do wymogów Unii Europejskiej.

To, że nadanie uprawnień wyborczych imigrantom nie potrzebuje zmian Konstytucji, potwierdził Trybunał Konstytucyjny, do którego zwróciła się grupa posłów z zapytaniem, czy nadanie lokalnych praw wyborczych cudzoziemcom-obywatelom państw członkowskich UE nie jest prawnie sprzeczne z Konstytucją.

Trybunał Konstytucyjny na podstawie wyroku z dnia 11 maja 2005 roku zaprzeczył tym zarzutom, uznając iż: „Czynne i bierne prawo wyborcze w wyborach lokalnych (...) przysługujące w państwie członkowskim miejsca zamieszkania obywatelom UE, nieposiadającym 
obywatelstwa polskiego, nie zagrażają Rzeczypospolitej Polskiej jako dobru wspólnemu wszystkich obywateli, z uwagi na konstytucyjnie określony charakter wspólnot samorządowych oraz nałożone na nie zadania i przyznane w związku z tym kompetencje. Zgodnie z Konstytucją RP (art. 16 ust. 1) wspólnotę samorządową stanowi z mocy prawa »ogół mieszkańców jednostek zasadniczego podziału terytorialnego«. Wspólnoty te tworzą odpowiednio wszyscy mieszkańcy gmin, powiatów i województw z mocy prawa, jakim jest Konstytucja RP” (Wyrok Trybunału Konstytucyjnego 2005).

Na podstawie interpretacji wspólnoty samorządowej oraz Wyroku Trybunału powstają pytania o rozszerzeniu lokalnych praw wyborczych na cudzoziemców-obywateli państw trzecich, jak pisze Agnieszka Piekutowska: „Niestety, uznanie, iż wspólnota samorządowa stanowi wspólnotę mieszkańoów, nie stanowiło dla polskiego ustawodawcy przesłanki dla przyznania praw wyborczych w wyborach lokalnych w Polsce dla cudzoziemoów z państw trzecich" (Piekutowska 2016, s. 188).

Prawo udziału w referendum lokalnym

Zgodnie z art. 3 Ustawy o referendum lokalnym, „(...) w referendum mają prawo brać udział osoby stale zamieszkujące na obszarze danej jednostki samorządu terytorialnego, posiadające czynne prawo wyborcze do organu stanowiącego tej jednostki" (Ustawa o referendum lokalnym 2000, art. 3). Zatem prawo udziału w referendum poza obywatelami Polski mają cudzoziemcy z UE. Prawo to ogranicza się jedynie do poziomu gminy.

Chociaż Konstytucja Polski zastrzega prawo udziału w referendum lokalnym dla wszystkich mieszkańców wspólnoty samorządowej bez względu na to, czy są obywatelami polskimi, czy cudzoziemcami: „Członkowie wspólnoty samorządowej mogą decydować, w drodze referendum, o sprawach dotyczących tej wspólnoty, w tym o odwołaniu 
pochodzącego z wyborów bezpośrednich organu samorządu terytorialnego." (Konstytucja ... 1997, art. 170).

Dorota Pudzianowska wnioskuje, iż: „Z punktu widzenia Konstytucji RP niema obiektywnych przesłanek uzasadniających różnetraktowanie cudzoziemców unijnych i cudzoziemców z państw trzecich w dostępie do tych praw. Cechą relewantną w przypadku wyborów lokalnych oraz udziału w referendum na szczeblu lokalnym jest bycie mieszkańcem jednostki zasadniczego podziału terytorialnego i tym samym współtworzenie wspólnoty samorządowej. Okoliczność, czy jest się obywatelem tego, czy innego państwa nie powinna mieć w tym wypadku znaczenia” (Pudzianowska 2014, s. 109).

Zatem wykluczenie cudzoziemców z państw trzecich z prawa decydowania w drodze referendum o sprawach dotyczących wspólnoty, której są członkami, nie następuje z mocy Konstytucji, lecz z Ustawy o referendum lokalnym. Dlatego też nadanie takich uprawnień nie będzie sprzeczne z Konstytucją i nie wymaga jej zmiany.

Prawo do zrzeszania się

Konstytucja Polski zapewnia każdemu wolność zrzeszania się (Konstytucja...1997, art. 58). Warto zauważyć, że „, w polskim języku prawnym „zrzeszenie” jest pojęciem ogólnym i abstrakcyjnym. Znane są różne rodzaje zrzeszeń, a występują one pod postacią i w formie prawnej czy to związku zawodowego, czy to partii politycznej" (Pudzianowska 2014, s. 110).

J ednocześnie art. 11 Konstytucji RP zastrzega prawo zrzeszania się wyłącznie obywatelom polskim: „Rzeczpospolita Polska zapewnia wolność tworzenia i działania partii politycznych. Partie polityczne zrzeszają na zasadach dobrowolności i równości obywateli polskich w celu wpływania metodami demokratycznymi na kształtowanie polityki państwa" (Konstytucja... 1997, art. 11). 
Pytanie o możliwości członkostwa cudzoziemców w partiach politycznych pojawiło się, kiedy cudzoziemoom z UE zostały nadane prawa wyborcze na szczeblu lokalnym, to znaczy wraz z wejściem Polski do UE. Możliwość czynnego i biernego udziału w wyborach nie może być skutecznie realizowana bez takiego uprawnienia, szczególnie prawo kandydowania.

Rola partii w procesie wyborczym jest oczywista. Zdaniem Komisji, pozbawienie cudzoziemców-obywateli Unii prawa do wstępowania do partii politycznych lub ich zakładania w państwach członkowskich, w których zamieszkują, może stanowić przeszkodę w efektywnym wykonywaniu przez nich prawa do kandydowania w wyborach lokalnych i w wyborach do Parlamentu Europejskiego. W 2012 r. Komisja wezwała Polskę do zmiany istniejącego prawa, domagając się zapewnienia cudzoziemcom-obywatelom UE zamieszkałym wPolsce prawa wstępowania do partii politycznych lub zakładania takich partii. Pozytywne stanowisko w sprawie możliwości wprowadzenia takiej zmiany zajęła Rada Legislacyjna przy Prezesie Rady Ministrów, w opinii której art. 11 ust. 1 Konstytucji RP nie stoi w sprzeczności z rozwiązaniem ustawowym dopuszczającym członkostwo w partiach politycznych obywateli UE stale zamieszkujących w Polsce (Pudzianowska 2014, s. 110-111).

Prawo do tworzenia czy przestępowania do partii politycznych, a dokładniej jego brak, jest barierą w skutecznej realizacji wyborczych praw cudzoziemców. Ten stan prawny do tej pory nie uległ zmianie.

\section{Przyczyny aktualnej sytuacji prawnej}

Po tym wstępie należy wyjaśnić, dlaczego w Polsce stosowane są różne regulacje prawne w stosunku do dwóch różnych grup cudzoziemców.

Jak już zostało zaznaczone wyższej, takie uwarunkowania prawne uksztaltowały się w związku z wejściem Polski do Unii Europejskiej.

J ednym z wymogów przystą̧ienia Polski do UE była konieczność dopasowania prawa krajowego do wymogów unijnych. 
Ustawodawstwo Unii Europejskiej przewiduje, iż każdy obywatel UE, który przebywa w państwie członkowskim, którego nie jest obywatelem, ma prawo do głosowania i kandydowania na wyborach na szczeblu lokalnym w tym państwie na tych samych zasadach co obywatele tego państwa.

Głównymi aktami prawnymi Unii Europejskiej, które określają prawo cudzoziemców będących obywatelami UE do udziału w wyborach lokalnych i wyborach do Parlamentu Europejskiego, jest Traktat ustanawiający Wspólnotę Europejską, Karta Praw Podstawowych UE, Dyrektywa UE 93/ 109/WE z dnia 6 grudnia 1993 roku w sprawie ustanowienia szczegółowych warunków wykonywania prawa głosowania i kandydowania w wyborach do Parlamentu Europejskiego przez obywateli Unii mających miejsce zamieszkania w państwie członkowskim, którego nie są obywatelami, Dyrektywa 94/80/WE z dnia 19 grudnia 1994 roku ustanawiająca szczegółowe warunki wykonywania prawa głosowania i kandydowania w wyborach lokalnych przez obywateli Unii mających miejsce zamieszkania w państwie członkowskim, którego nie są obywatelami.

W związku z tym, zgodnie z artykułem 19 Traktatu ustanawiającego Wspólnotę Europejską, „[...] każdy obywatel Unii mający miejsce zamieszkania w państwie członkowskim, którego nie jest obywatelem, ma prawo głosowania i kandydowania w wyborach lokalnych w państwie członkowskim, w którym ma miejsce zamieszkania, na takich samych zasadach jak obywatele tego państwa” (Traktat ustanawiający Wspólnotę Europejską 2006, art. 19).

Artykuł 40 Karty Praw Podstawowych UE wymienia to uprawnienie oraz w artykule 39 określa prawo cudzoziemców-obywateli UE do głosowania i kandydowania w wyborach do Parlamentu Europejskiego w państwie członkowskim, w którym ma miejsce zamieszkania, na takich samych warunkach jak obywatele tego państwa (Karta Praw Podstawowych Unii Europejskiej 2000, art. 39, 40). 
Dyrektywa UE 93/ 109/WE z dnia 6 grudnia 1993 roku oraz Dyrektywa 94/ 80/ WE z dnia 19 grudnia 1994 roku również potwierdzają owe wyborcze uprawnienia dla cudzoziemców z UE. Dodatkowo artykuł 3 ust. b Dyrektywy 94/ 80/ WE zaznacza, iż aby mieć prawo głosu cudzoziemiec z UE powinien spełniać pozostałe warunki prawa głosowania i kandydowania w wyborach, jakie odnośne państwo stawia swoim obywatelom (Dyrektywa 94/ 80/WE 1994, art. 3).

Oprócz tego, Dyrektywa 94/80/WE określa pewne ograniczenia praw wyborczych cudzoziemców z UE. W szczególności w artykule 5 między innymi ograniczeniami zaznaczono, iż państwa członkowskie mogą w swoim prawie wewnętrznym zastrzec, że tylko ich obywatele będą wybierani na urząd kierownika organu wykonawczego, jego zastępcy lub członków kierowniczego kolegialnego organu wykonawczego (Dyrektywa 94/ 80/WE 1994, art. 5).

Polska, dopasowując krajowe prawo do unijnego, skorzystała z przepisów Dyrektywy 94/ 80/WE, przyznawszy cudzoziemcom z UE bierne i czynne prawa wyborcze w wyborach samorządowych na szczeblu gminy, jednak w wyborach na wójta (burmistrza lub prezydenta miasta) jedynie bierne prawo wyborcze bez możliwości kandydowania, nie przyznano też cudzoziemcom z UE praw wyborczych na szczeblu powiatowym czy wojewódzkim.

Dlatego Polska wprowadziła minimalny zakres zmian, to znaczy tylko te zmiany, które były wymagane przez prawo unijne, stosując je jedynie na poziomie gminy (podstawowej jednostce samorządu terytorialnego) oraz nie przewidując żadnych uprawnień politycznych dla cudzoziemców z państw trzecich, ponieważ prawo unijne tego nie przywidywało.

Podsumowanie

Jak wynika z uwarunkowań prawno-międzynarodowych, imigranci mieszkający wPolscei będący obywatelami państwtrzecich, nie mają takich 
samych praw wyborczych, jak imigranci będący jednocześnie obywatelami państw członkowskich UE (Trojanowska-Strzęboszewska 2013, s. 103).

W następstwie tego, według ostatniego raportu MIPEX (oraz według poprzednich), Polska pod względem zagwarantowania migrantom praw politycznych oraz możliwości partycypacji w życiu politycznym państwa znajduje się na przedostatnim miejscu, to znaczy na 37, ostatnie miejsce - 38 zajmuje Rumunia. Wyprzedza Polskę Turcja, która została oceniona na 5 punktów więcej, aniżeli Polska (MIPEX b.r.).

Polskie regulacje prawne pod względem gwarancji cudzoziemcom praw politycznych należą dojednych z najbardziej restrykcyjnych wEuropie ponieważ między innymi pozostawiają największą grupę cudzoziemców - imigrantów z państw trzecich - wykluczonymi z życia politycznego państwa, co nie sprzyja rozwojowi ich partycypacji politycznej oraz integracji.

Chociaż Polska liberalizuje dostęp do rynku pracy dla migrantów z państw trzecich oraz umożliwia im nabycie tych czy innych tytułów pobytowych, jednocześnie tworzy warunki niesprzyjające do dalszej integracji cudzoziemców z polskim społeczeństwem.

\section{Zakończenie}

Warto wziąć pod uwagę to, iż w Polsce z każdym rokiem rośne liczba cudzoziemców zamieszkujących na podstawiezezwolenia na pobyt stały czy na podstawie zezwolenia na pobyt rezydenta długoterminowego Unii Europejskiej na czas nieokreślony. Za ubiegłych kilka lat zdążyli oni już zająć różne pozycje w polskim społeczeństwie, stając sięjego nierozdzielną częścią.

J ednak kwestia nadania cudzoziemcom pochodzącym z państw trzecich praw politycznych na szczeblu lokalnym, mimo rosnącego poziomu imigracji, wciąż pozostaje problemem politycznie i publicznie pominiętym, co może przyczynić się do różnych wyzwań polityczno-społecznych. 
Przyznanie praw politycznych cudzoziemcom z państw trzecich na szczeblu lokalnym nie może być odkładane na później, tym bardziej ze względu na brak przeszkód prawnych do wprowadzenia takich uprawnień, które powinny zapewnić demokratyczne równouprawnienia wszystkim grupom imigrantów, co zapobiegałoby ich dyskryminacji i marginalizacji.

\section{Literatura}

Dyrektywa 93/ 109/WE (1993), Dz.U. L 329, 30/ 12/ 1993 P. 0034- 0038 Dyrektywa 94/ 80/WE (1994), Dz.U. L 368

Karta Praw Podstawowych Unii Europejskiej (2000), Dz.Urz. UE C 83 Konstytucja Rzeczypospolitej Polskiej z dnia 2 kwietnia 1997 r. uchwalona przez Zgromadzenie Narodowe w dniu 2 kwietnia 1997 r., przyjęta przez Naród w referendum konstytucyjnym wdniu 25 maja 1997 r., podpisana przez Prezydenta Rzeczypospolitej Polskiej w dniu 16 lipca 1997 r. (1997), Dz.U. 1997 nr 78 poz. 483

Konwencja o uczestnictwie cudzoziemców wżyciu publicznym na szczeblu lokalnym (1992), Strasburg, 5 lutego, ETS Nr 144, http:// www. umwd.dolnyslask.pl/fileadmin/fundusze_europejskie/ZGR/ emilia _romania___gallery/foto/obwo_dniepropietrowski/Konwencja_o _uczestnictwie_cudzoziemcow_w_zyciu_publicznym_na_szczebl u_lokalnym.pdf [4.11.2018]

Krzywoń A. (2014), Komentarz do ekspertyzy prawnej dotyczacej uczestnictwa politycznego i praw wyborczych cudzoziemców z państw trzecich $w$ Polsce, (w:) Prawa wyborcze dla cudzoziemców tak czy nie?, (red.) Łodziński S., Pudzianowska D., SzaranowiczKusz M., Międzynarodowa Organizacja do spraw Migracji (IOM), Instytut Socjologii UW, Warszawa

Lesińska M. (2013), Inkluzja polityczna imigrantów we wspótczesnej Europie, Warszawa, Scholar 
Lesińska M. (2008), Prawa polityczne i wyborcze oraz ich rola w procesie inkluzji politycznej imigrantów, (w:) Problemy integracji imigrantów. Koncepcje, badania, polityka, (red.) Grzymała-Kazłowska A., Łodziński S., Warszawa, Wydawnictwa Uniwersytetu Warszawskiego

Urząd do Spraw Cudzoziemców (b.r.- a), Mapy i dane statystyczne imigrantów $i$ stużb migracyjnych Polsk / Ważne, https://migracje.gov.pl/ , [28.10.2018]

Urząd do Spraw Cudzoziemców (b.r.-b), Porównanie lat 2018/2013, https:/ / migracje.gov.pl/statystyki/zakres/ polska/typ/ dokumenty/ widok $/ \mathrm{mapa} / \mathrm{rok} / 2018 / \mathrm{rok} 2 / 2013 /$ ? $=0.8738 \& \mathrm{y}=0.8635 \&$ level $=$ 0.72512 [28.10.2018]

MIPEX (b.r.), Migrant Integration Policy Index, http:/ / www.mipex.eu / political-par-ticipation [30.10.2018]

Piekutowska A. (2016), Prawa wyborcze imigrantów. Refleksje na tle instytucji obywatelstwa europejskiego, „Białostockie Studia Prawnicze" z. 20/A

Pudzianowska D. (2014), Prawa wyborcze i inne prawa polityczne cudzoziemców z państw trzecich $w$ Polsce, (w:) Prawa wyborcze dla cudzoziemców - tak czy nie?, (red.) Łodziński S., Pudzianowska D., Szaranowicz-Kusz M., Międzynarodowa Organizacja do spraw Migracji (IOM), Instytut Socjologii UW, Warszawa

Urząd do Spraw Cudzoziemców (2017), Raport roczny - legalizacja pobytu, https:// udsc.gov.pl/statystyki/ raporty-okresowe/ raport-rocz ny-legalizacja-pobytu/ 2017-2/ , [28.10.2018]

Traktat ustanawiający Wspólnotę Europejską (2006), Dz.Urz. UE 2006 C 321E

Trojanowska-Strzęboszewska M. (2013), Prawo do udziału w wyborach na szczeblu lokalnym jako forma partycypacji politycznej imigrantów. Polska na tle innych krajów europejskich, „Political Preferences", $\mathrm{nr} 7$

Ustawa o referendum lokalnym (2000), Dz.U. 2000 nr 88 poz. 985 
Ustawa o zmianie ustawy - Ordynacja wyborcza do rad gmin, rad powiatów i sejmików województw oraz niektórych innych ustaw (2004), Dz.U. nr 102 poz. 1055

Wyrok Trybunału Konstytucyjnego (2005), Dz.U. nr 86 poz. 744 